\title{
¿ALPARGATAS SÍ, LIBROS NO? PERONISMO, LITERATURA E SETORES POPULARES NA OBRA DE LUIS HORACIO VELÁZQUEZ (1944-1954)

\author{
¿ALPARGATAS SÍ, LIBROS NO? PERONISMO, LITERATURA Y SECTORES \\ POPULARES EN LA OBRA DE LUIS HORACIO VELÁZQUEZ (1944-1954)
}

\section{ESPADRILLES BUT NOT BOOKS? PERONISM, LITERATURE AND WORKING- CLASS SECTORS IN THE WORK OF LUIS HORACIO VELÁZQUEZ (1944-1954)}

\section{ALPARGATAS SI, LIBROS NO? PÉRONISME, LITTÉRATURE ET CLASSES POPULAIRES DANS L'CEUVRE DE LUIS HORACIO VELAZQUEZ (1944-1954)}

\section{布鞋可以，书本不行?}

皮隆主义，文学和民众阶层在阿根廷作家维拉凯斯的作品中的反映(1944-1954)

DOI: 10.5533/1984-2503-20135306

Paulo Renato da Silva ${ }^{1}$

\section{RESUMO}

A obra do escritor argentino Luis Horacio Velázquez indica que o governo do presidente Juan Domingo Perón (1946-1955) teve uma política cultural, aspecto minimizado, ou mesmo negado pela historiografia sobre o peronismo até a década de 1990. Porém, sua obra sugere que Perón enfrentou problemas para concretizar elementos importantes de sua política cultural, como o controle da "violência" dos trabalhadores, a valorização do trabalho, a defesa dos papéis tradicionalmente atribuídos às mulheres e a crítica aos vícios e aos relacionamentos extraconjugais.

Palavras-chave: Peronismo, Intelectuais, Setores Populares, Literatura.

\section{RESUMEN}

La obra del escritor argentino Luis Horacio Velázquez indica que el gobierno del presidente Juan Domingo Perón (1946-1955) tuvo una política cultural, aspecto minimizado o negado por la historiografía sobre el peronismo hasta la década de 1990. Su obra sugiere que Perón ha enfrentado problemas para concretizar elementos importantes de su política cultural, como el control de la "violencia" de los trabajadores, la valoración

\footnotetext{
${ }^{1}$ Doutor em História pela Universidade Estadual de Campinas (UNICAMP) e professor da Universidade Federal da Integração Latino-Americana (UNILA) de Foz do Iguaçu (PR). E-mail: paulo.silva@unila.edu.br .
} 
del trabajo, la defensa de los papeles tradicionalmente atribuidos a las mujeres y la crítica a los vicios y a los relacionamientos extraconyugales.

Palabras clave: Peronismo, Intelectuales, Sectores Populares, Literatura.

\section{ABSTRACT}

The work of Argentine author Luis Horacio Velázquez demonstrates that the government of President Juan Domingo Perón (1946-1955) featured cultural policies, and that these were downplayed or even denied by historiography on Peronism until the 1990s. Velázquez's work suggests that Perón did however face difficulties in consolidating important elements of his cultural policies, such as the control of "violence" among workers, the valuing of work, the defence of roles traditionally attributed to women and the criticism of addiction and extra-marital relationships.

Key words: Peronism, Intellectuals, Working-Class Sectors, Literature.

\section{RÉSUMÉ}

L'œuvre de l'écrivain argentin Luis Horacio Velázquez nous montre que le gouvernement du président Juan Domingo Perón (1946-1955) était doté d'une politique culturelle, un aspect minimisé, voire ignoré par l'historiographie du péronisme jusqu'aux années 1990. Les textes de notre écrivain suggèrent que Perón a fait face à de nombreux problèmes pour concrétiser d'importants éléments de sa politique culturelle, comme le contrôle de la «violence » des travailleurs, la mise en valeur du travail, la défense des rôles traditionnellement attribués aux femmes et la critique du vice et des rapports extraconjugaux.

Mots-clés: Péronisme, Intellectuels, Classes populaires, Littérature.

\section{摘要}

阿根廷作家路易斯 . 贺拉修 . 维拉凯斯(Luis

Horacio

Velázquez)

的文学作品中指明阿根廷总统潢 . 多明戈 ·皮隆(1946-1955)

制定执行了文化政策，这一事实曾经被历史学界低估忽略或否定一直到1990年代。然而维 拉凯斯的作品也指出皮隆在执行其文化政策时遇到了些具体的困难, 比如怎样控制工人阶层 的”暴力”, 宣扬劳动价值观, 维护妇女的传统角色, 反对酗酒嫖娼等不良行为, 反对婚外恋 情等。 
关键字：皮隆主义，知识分子，民众阶级，文学

O slogan ¡Alpargatas sí, libros no!, supostamente entoado em eventos do governo do presidente argentino Juan Domingo Perón (1946-1955), ajudou por décadas a alimentar a visão segundo a qual o peronismo, em seus primórdios, não teria tido uma política cultural, e demonstraria sua incompatibilidade com os intelectuais. Segundo Fermín Chávez, os antiperonistas difundiram essa visão a partir de uma conferência do socialista Américo Ghioldi pronunciada em dezembro de 1945, dois meses antes da primeira eleição de Perón em 1946:

En esta época argentina de negación sistemática [...] de la democracia, de la Constitución, de las figuras e instituciones históricas, se ha llegado hasta a negar validez a la inteligencia y al libro en el grito que recorrió las calles y que debe ser analizado en las aulas. Alpargatas sí; libros, no; es un grito del alma, de cierto tipo de alma. ${ }^{2}$

Trata-se de uma forma de desqualificar o peronismo e os setores populares, base social reivindicada por Perón. Entretanto, essa visão extrapolou os embates políticos diretos e foi incorporada pela historiografia. Encontramos essa visão, por exemplo, em Félix Luna: "[...] ¿quién leía libros? La mayoría de los intelectuales no formaban parte del oficialismo, pero [...] no tuvieron una actitud militante antiperonista; más bien fue la suya una posición indiferente [...].”3 Em artigo de 2004, Flavia Fiorucci defende que essa "indiferença" era recíproca, ou seja, também partia de Perón e do governo em relação aos intelectuais:

La identidad obrera de este movimiento y el carácter autoritario del régimen son centrales a la hora de comprender la falta de interés en la alta cultura y en sus propios cuadros intelectuales. [...]. Buscaba recomponer la relación de fuerzas en la sociedad, y en el nuevo esquema ni los intelectuales ni la cultura de élite eran importantes. Perón desconfiaba de los intelectuales y del mundo de las ideas en general, al cual anteponía la acción. ${ }^{4}$

${ }^{2}$ Chávez, Fermín (2004). Alpargatas y Libros: diccionario de peronistas de la cultura II, Buenos Aires: Theoría, 2004, p. 91. "Nesta época argentina de negação sistemática [...] da democracia, da Constituição, das figuras e instituições históricas, se chegou até a negar validez à intelectualidade e ao livro no grito que percorreu as ruas e que deve ser analisado nas salas de aula. Alpargatas sim; livros, não; é um grito da alma, de certo tipo de alma." [Tradução do autor].

${ }^{3}$ Luna, Félix (1986). Perón y su Tiempo, Buenos Aires: Sudamericana, v. 1, p. 495. "[...] quem lia livros? A maioria dos intelectuais não fazia parte do governo, mas [...] também não foram antiperonistas militantes; tiveram uma posição de indiferença [...]." [Tradução do autor].

${ }^{4}$ Fiorucci, Flavia (2004). “¿Aliados o Enemigos? Los Intelectuales en los Gobiernos de Vargas e Perón.” In Estudios Interdisciplinarios de America Latina y el Caribe, v. 15, n. 2, p. 11. Disponível em: $<$ www.tau.ac.il/eial/XV_2/fiorucci.html>. Acesso em: 2 maio 2005. "A identidade operária deste movimento e o caráter autoritário do regime são centrais na hora de compreender a falta de interesse na alta cultura e em 
Outros autores, contudo, lançaram dúvidas sobre essa visão. Na década de 1980, John King apontava que o peronismo ainda permanecia "[...] en gran parte inexplorado en el campo cultural [...]." Mariano Ben Plotkin também aponta essa lacuna: segundo o autor, no início da década de 1990, os "[...] aspectos simbólicos del peronismo recién comenzaban a ser explorados."

Um exemplo da incorporação da cultura como objeto da historiografia sobre o peronismo é o livro Multidões em Cena, de Maria Helena Rolim Capelato. A autora destaca que a literatura foi uma "arma de luta" durante o governo de Perón, não apenas para os antiperonistas, mas também para os peronistas. "Com as armas das letras, peronistas e antiperonistas travaram uma luta destruidora da imagem da "sociedade unida e harmônica"', 7 Concordamos com a autora, mas, neste trabalho, pretendemos acrescentar uma nuance: a produção literária do período não indica somente as tensões entre antiperonistas e peronistas, mas também do peronismo com sua própria base social, como indica a obra de Luis Horacio Velázquez.

Também destacamos a necessidade de a historiografia revisar as versões segundo as quais os escritores peronistas eram "de segunda linha" secundário que a cultura teria tido no governo de Perón. Em primeiro lugar, formavam um grupo muito heterogêneo para ser agrupado sob uma mesma qualificação. Além disso, cabe dar historicidade ao que se considera como a "boa" literatura argentina. Até as décadas de 1940 e 1950, escritores herdeiros, por exemplo, do melodrama, como acreditamos ser Luis Horacio Velázquez, dividem espaço com nomes como Jorge Luis Borges que, a partir da década de 1960, se tornou um dos principais referenciais da literatura argentina ao se consolidar o reconhecimento internacional, sobretudo, da literatura fantástica produzida no país. ${ }^{9}$ A queda de Perón em 1955 e a consolidação da

seus próprios quadros intelectuais. [...]. Buscava recompor a relação de forças na sociedade, e no novo esquema nem os intelectuais nem a cultura de elite eram importantes. Perón desconfiava dos intelectuais e do mundo das ideias em geral, ao qual antepunha a ação." [Tradução do autor].

${ }^{5}$ King, John (1989). Sur: estudio de la revista argentina y de su papel en el desarrollo de una cultura (19311970), Cidade do México: Fondo de Cultura Económica, p. 17. "[...] em grande parte inexplorado no campo cultural [...]." [Tradução do autor].

${ }^{6}$ Plotkin, Mariano Ben (2007). Mañana es San Perón: propaganda, rituales políticos y educación en el régimen peronista (1946-1955), Caseros: Editorial de la Universidad Nacional de Tres de Febrero, p. 11. "[...] aspectos simbólicos do peronismo apenas começavam a ser explorados." [Tradução do autor].

Capelato, Maria Helena Rolim (2009). Multidões em Cena: propaganda política no varguismo e no peronismo. 2. ed., São Paulo: Ed. UNESP, p. 129.

Ibidem, p. 127.

${ }^{9}$ Em seu livro sobre as "narrativas sentimentais" das décadas de 1910 e 1920, Beatriz Sarlo destaca a 
literatura fantástica é o que explicam a condição "de segunda linha" atribuída aos escritores peronistas.

Talvez por isso Luis Horacio Velázquez seja ainda tão pouco conhecido, inclusive na Argentina. Sua obra mostra como o governo de Perón via a literatura como um instrumento fundamental não apenas de propaganda política, mas também de normatização dos setores populares. Neste trabalho seguimos Michel de Certeau, para quem uma política cultural é "[...] um conjunto mais ou menos coerente de objetivos, de meios e de ações que visam à modificação de comportamentos, segundo princípios ou critérios explícitos."10 Contudo, a obra do escritor nos mostra que haveria um desnível entre o discurso peronista e as práticas atribuídas à sua própria base social. Esse desnível nos leva a repensar a relação entre Perón e os setores populares.

O nome de Leopoldo Marechal (1900-1970) costuma ser destacado dentre os escritores peronistas. Entretanto, poucos conceberam tão intensamente a sua obra a partir do discurso peronista como Luis Horacio Velázquez, nascido em 25 de agosto de 1912 em La Plata, capital da Província de Buenos Aires. No acervo da biblioteca de Perón encontramos dois livros do escritor, Dos Letras Milagrosas, reunião de poemas, e Los Años Conmovidos, o qual comentaremos a seguir. ${ }^{11}$ Luis Horacio Velázquez alcançou destaque durante o governo de Perón e foi publicado por editoras importantes como Claridad $^{12}$, Guillermo Kraft e Emecé. Em tempo, no período, a Emecé também foi uma das principais editoras de um antiperonista ferrenho como Jorge Luis Borges.

Entre 1952 e 1955, Luis Horacio Velázquez foi presidente da Comissão Protetora

necessidade de não se exaltar acriticamente estes textos. Contudo, a autora também alerta que é preciso dar a devida historicidade a essas narrativas para evitar uma visão elitista. "[...] me interesé en el problema de cómo leer una literatura que se remite toda al pasado: por la elección de su sistema narrativo, por su discurso, por sus temas; y cómo lograr abordarla sin suficiencia elitista [...]." Sarlo, Beatriz (2004). El Imperio de los Sentimientos: narraciones de circulación periódica en la Argentina (1917-1927), Buenos Aires: Norma, p. 20. "[...] me interessei pelo problema de como ler uma literatura que se remete toda ao pasado: pela escolha de seu sistema narrativo, por seu discurso, por seus temas; e como conseguir abordála sem arrogância elitista [...]." [Tradução do autor].

${ }^{10}$ Certeau, Michel de (1995). A Cultura no Plural, Campinas: Papirus, p. 195.

11 Swiderski, Graciela (Org.) (1997). Biblioteca Juan Domingo Perón: bibliografía sobre el peronismo, Buenos Aires: Archivo General de la Nación, p. 161. É interessante destacar que nesta relação organizada por Swiderski não consta nenhum título de Leopoldo Marechal.

${ }^{12}$ A editora Claridad foi uma das mais populares nas décadas de 1930 e 1940 pelos preços acessíveis de suas publicações. Segundo Antonio Zamora, diretor da Claridad, a editora vendeu aproximadamente 1 milhão de exemplares em menos de dez anos. De acordo com Zamora, inicialmente, os livros tinham uma tiragem média de 10 mil exemplares, mas, já na década de 1930, as tiragens chegavam a 30 mil. Ver: Sarlo, Beatriz (1997). "Buenos Aires, Cidade Moderna". In Paisagens Imaginárias: intelectuais, arte e meios de comunicação, São Paulo: EDUSP, p. 199-217. 
de Bibliotecas Populares, ligada ao Ministério da Educação. ${ }^{13}$ Nessa época foi realizado um censo que levou à elaboração de um guia das bibliotecas. ${ }^{14} \mathrm{O}$ censo indica a atuação do governo de Perón na esfera cultural e demonstra uma preocupação quanto à leitura feita pelos argentinos. Na apresentação do guia, Luis Horacio Velázquez pergunta: “¿Contribuye el caudal de sus colecciones a la formación de una conciencia, de un espíritu argentino, de un alma nacional? ${ }^{15}$ Como presidente da Comissão Protetora de Bibliotecas Populares, Luis Horacio Velázquez ainda foi jurado de concursos literários promovidos pelo governo. O escritor foi jurado, por exemplo, do Prêmio Eva Perón de Literatura para "obras de imaginação em prosa". ${ }^{16}$

Antes de ser poeta e escritor, Luis Horacio Velázquez trabalhou como secretário e começou a cursar universidade, mas teve que abandonar os estudos devido a problemas econômicos. Depois, trabalhou em frigoríficos na cidade de Berisso, Província de Buenos Aires. Nessa época escreveu o folheto Carne de Fábrica (1935), no qual denunciou as condições adversas de trabalho e defendeu os trabalhadores do setor: os trabalhadores da indústria da carne seriam, justamente, um dos principais apoios recebidos inicialmente por Perón, como assinala, por exemplo, Daniel James:

Sob a liderança de Cipriano Reyes, os trabalhadores estabeleceram o Sindicato Autónomo de Obreros de la Industria de la Carne em 1944. Esse foi um dos primeiros sindicatos a ser cortejado por Juan Perón quando ele era secretário do Trabalho no governo militar estabelecido em 1943. Os trabalhadores da indústria de frigoríficos de Berisso tiveram uma atuação crucial na mobilização de 17 de outubro de 1945, a qual obrigou o governo militar a libertar Perón da prisão e o lançou em sua escalada até a Presidência. ${ }^{17}$

\footnotetext{
${ }^{13}$ As bibliotecas populares são entidades civis autônomas custeadas total ou parcialmente pelo Estado argentino. Surgiram no governo de Domingo Faustino Sarmiento (1868-1874). Leandro H. Gutiérrez e Luis Alberto Romero destacam que a formação da maioria das bibliotecas populares foi uma iniciativa de setores da elite. Contudo, também destacam que as diretorias das bibliotecas eram compostas por membros provenientes dos setores populares, que nelas alcançavam reconhecimento e distinção social (Gutiérrez, Leandro; Romero, Luis Alberto (2007). Sectores Populares, Cultura y Política: Buenos Aires en la entreguerra, Buenos Aires: Siglo XXI).

14 O censo aponta a relevância cultural e política das bibliotecas populares. O número de leitores/frequentadores, somente na cidade de Buenos Aires, era de aproximadamente 500 mil por ano. Outro dado importante, apresentado pelo guia, é a mudança de nome de muitas bibliotecas após a ascensão do peronismo. Para citar apenas um exemplo, a Biblioteca Popular Esteban Echeverría de Buenos Aires passou a se chamar Biblioteca Popular Eva Perón (Velázquez, Luis Horacio (1954b). Guia de Bibliotecas Argentinas, Buenos Aires: Ministerio de Educación de la Nación; Dirección General de Cultura; Comisión Protectora de Bibliotecas Populares, t. 1, p. 29).

${ }^{15}$ Ibidem, p. 11. "Contribui o conjunto de suas coleções para a formação de uma consciência, de um espírito argentino, de uma alma nacional?' [Tradução do autor].

${ }_{16}$ La Prensa (1954), Buenos Aires, 6 de outubro.

17 James, Daniel (2004). "Contos narrados nas fronteiras: a história de doña María, história oral e questões de gênero". In Batalha, Claudio H. M; Silva, Fernando Teixeira; Fortes, Alexandre (Orgs.). (2004). Culturas de Classe: identidade e diversidade na formação do operariado, Campinas, SP: Ed. UNICAMP, p. 287-288. Em 1945, Perón era vice-presidente, Secretário do Trabalho e Ministro da Guerra do general Edelmiro
} 
Em 1946, nestes primórdios do peronismo, Luis Horacio Velázquez participou da redação do plano de governo de Domingo Alfredo Mercante (1898-1976), governador da Província de Buenos Aires (1946-1952). Mercante foi um dos principais líderes do 17 de outubro de 1945.

Quanto à sua trajetória literária, Luis Horacio Velázquez lançou, em 1942, o poema El Continente de la Esperanza, sobre a América. No ano seguinte, Pobres Habrá Siempre, que será aqui analisado, ficou em terceiro lugar em um concurso promovido pelo jornal Noticias Gráficas, o qual teve cinquenta e cinco participantes. Em 1944, o livro foi publicado pela editora Claridad. ${ }^{18}$ Pobres Habrá Siempre consiste em um desdobramento literário do folheto Carne de Fábrica. As primeiras edições tinham, inclusive, o subtítulo Novela de las Fábricas. O livro voltou a ser premiado em 1950, desta vez com o Primeiro Prêmio de Literatura Bonaerense, ou seja, da Província de Buenos Aires. Em 1952, o livro ganhou uma edição especial pela Guillermo Kraft, com capa dura e ilustrações de José G. Macuso. Em 1954, foi adaptado para o cinema por Carlos Borcosque, cineasta chileno radicado na Argentina. ${ }^{19}$

Em 1947, Luis Horacio Velázquez publicou o poema Territorio de Infancia. Em 1949, Los Años Conmovidos. Em 1950, outros dois poemas, Salmos del Siglo XX e El Regreso de la Diosa Caa-Yarí, ambos lançados pela Peña Eva Perón. ${ }^{20}$ Em 1951, foi publicado Dos Letras Milagrosas, livro que contém o poema Mujer de America, uma homenagem a Eva Perón. Em 1954 foi a vez de El Juramento, o terceiro texto de Luis Horacio Velázquez que analisaremos.

Para termos mais um exemplo da estreita relação do escritor com o peronismo,

Farrell (1944-1946), terceiro presidente da ditadura instaurada em 1943. A ditadura estava em crise pela vitória dos Aliados na Segunda Guerra Mundial (1939-1945). Perón era um dos principais alvos dos protestos dos grupos liberal-democráticos pelo acúmulo de poderes e pela popularidade que alcançou entre os setores populares ao implantar uma série de medidas sociais e trabalhistas. Em 9 de outubro, Perón renunciou aos cargos, mas os protestos continuaram. Para acalmar a oposição, o governo prendeu Perón no dia 13. Porém, em sua defesa, greves e manifestações de trabalhadores começaram a estourar pelo país e, no dia 17, uma grande concentração se formou na Praça de Maio, diante da Casa Rosada, sede do governo argentino, pedindo sua libertação. O governo cedeu, convocou eleições e Perón se elegeu em fevereiro do ano seguinte em uma disputa acirrada.

${ }^{18}$ Aqui analisaremos a versão original do livro. Luis Horacio Velázquez adicionou capítulos em edições posteriores. Ver: Campodónico, H. (1998). "Pobres Habrá Siempre (Luis Horacio Velázquez/Carlos Borcosque)". In Segundas Jornadas Internacionales de Literatura Argentina/Comparatística: actas, Buenos Aires: Instituto de Literatura Argentina "Ricardo Rojas", p. 81-101.

${ }^{19}$ A estreia, contudo, ocorreu apenas em 1958. Ver: Campodónico, H. (1998). Op. Cit.

${ }^{20}$ Além de editora, a Peña Eva Perón era um grupo formado por poetas e escritores peronistas que promoviam encontros literários que homenageavam Perón e Evita. 
Luis Horacio Velázquez voltou ao cargo de presidente da Comissão Protetora de Bibliotecas Populares em 1973, quando Perón retornou à Argentina depois do exílio iniciado com a "Revolução Libertadora", golpe de Estado que Ihe derrubou em 1955. Apesar de ter voltado ao cargo, o escritor, após o golpe de 1955, caiu gradualmente no ostracismo, a exemplo de outros escritores e intelectuais ligados ao peronismo. Apesar disso, em 1958 ainda publicou Vida de un Héroe: biografía del brigadier general Juan Esteban Pedernera, pela Editora Peuser. Assim, além da literatura, o escritor também incursionou pela história argentina com essa biografia do prócer da independência e das guerras civis do século XIX.

Vale ressaltar que não é nosso propósito realizar uma análise literária das narrativas selecionadas, mas pensá-las historicamente. Tampouco pretendemos nos deter profundamente em cada uma delas. Desenvolveremos uma análise por assuntos comuns às três narrativas e que são recorrentes no discurso peronista.

A Grande Buenos Aires é o principal ambiente de Pobres Habrá Siempre, Los Años Conmovidos e El Juramento. Além disso, muitos personagens nasceram ou têm sua origem familiar no interior do país, onde também transcorre parte das narrativas. Pobres Habrá Siempre começa com uma disputa de empregos em uma fábrica de Avellaneda, na Grande Buenos Aires. A família de Héctor, o protagonista, veio de Cuyo, no extremo oeste argentino. Em Los Años Conmovidos, Beatriz nasceu no norte da Argentina e a imprensa clandestina de operários, na qual Roberto, o seu futuro marido, começa a militar, fica em Avellaneda. Tempos depois, Roberto consegue emprego em Quilmes, também na Grande Buenos Aires. Em El Juramento, após o falecimento do pai, Alcides se muda com seus familiares do centro para os arredores de Buenos Aires.

Relacionada com a localização espacial, a construção desses personagens é feita a partir de uma oposição destes aos imigrantes europeus e ao imperialismo. Em Pobres Habrá Siempre, os patrões preferem contratar os estrangeiros e os trabalhadores argentinos são mais perseguidos pelo capataz da fábrica, Rossler, que, aliás, é estrangeiro. Em Los Años Conmovidos, Roberto milita por uma Argentina "livre do estrangeiro". Em El Juramento, Alcides lembra que a avó igualava os estrangeiros a ladrões, um ódio "orgulhoso e legítimo".

A ligação desses personagens com o interior e/ou com a Grande Buenos Aires, área de forte migração interiorana, assim como a oposição destes aos imigrantes europeus e ao imperialismo, indicam uma releitura da tradição liberal argentina do século 
XIX. ${ }^{21}$ De um modo geral, em Luis Horacio Velázquez a tradição liberal é invertida: o interior e os argentinos é que são valorizados em detrimento da capital, dos portenhos e dos estrangeiros. A origem interiorana daria aos personagens uma "autêntica" identidade argentina. Tradicionalmente, a historiografia sobre o peronismo destaca o interior e os migrantes argentinos que se estabeleceram em Buenos Aires e em seus arredores como as principais bases sociais do peronismo. $^{22}$

Vejamos alguns exemplos dessa valorização do interior em Luis Horacio Velázquez. Em Pobres Habrá Siempre é recordado com nostalgia como Gregorio Olmos, assalariado em Buenos Aires, vivia antes no interior:

Era feliz, dueño de sí [...] Tiempos en que las distancias eran días, los días jornadas sin amargura y los arribos partidas hacia nuevos aventurados rumbos $y$ dichosas labores. Por contraste, se le vuelve su condición de asalariado actual la de un prisionero condenado a trabajos forzados. ${ }^{23}$

Em outra passagem, a vida urbana é vista como um "ostracismo sem ar". Em Los Años Conmovidos, Beatriz e Roberto, quando moravam em uma quinta, receberam uma vez a visita de parentes que viviam em Buenos Aires. "- Qué fresco tan agradable. En la Capital respiramos gases, no aire."24 Um dos capítulos do livro, inclusive, se chama Gente de campaña, gente de ciudad, no qual Beatriz, de passagem por Buenos Aires, enfrenta o desdém de amigas e parentes por ter se casado e por suas roupas simples, representação que a enquadra no modelo de mulher defendido pelo discurso peronista. ${ }^{25}$

${ }^{21}$ Em Facundo (1845), o liberal e unitário Domingo Faustino Sarmiento (1811-1888), que, conforme mencionado, foi presidente entre 1868 e 1874, analisou as guerras civis do período entre unitários e federalistas como um confronto entre a civilização, que estaria presente nas cidades e nos imigrantes europeus, e a barbárie, que seria representada pelo interior e pelos nativos, nos quais o federalismo se sustentaria. "[...] os progressos da civilização se acumulam em Buenos Aires somente; o pampa é um péssimo condutor para levá-la e distribuí-la nas províncias [...]." (Sarmiento, Domingo Faustino (1996). Facundo: civilização e barbárie, Petrópolis: Vozes, p. 69).

${ }^{22}$ Ver: Germani, Gino (1968). Politica y Sociedad en una Epoca de Transicion: de la sociedad tradicional a la sociedad de masas, Buenos Aires: Paidos.

${ }^{23}$ Velázquez, Luis Horacio (1944). Pobres Habrá Siempre, Buenos Aires: Claridad, p. 50. "Era feliz, dono de si [...] Tempos nos quais as distâncias eram dias, os dias jornadas sem amargura e as chegadas o início de novas aventuras e bons trabalhos. Agora, sentia sua condição atual de assalariado como a de um prisioneiro condenado a trabalhos forçados." [Tradução do autor]. Nessa e em outras passagens de Luis Horacio Velázquez encontramos releituras do poema Martín Fierro (1872-1879) de José Hernandez (18341886), considerado um contraponto a Sarmiento por valorizar o gaúcho e o campo. A seguir, o gaúcho Martín Fierro lembra a vida que tinha antes de ser forçado a lutar nas guerras civis, de modo parecido ao que acabamos de ver em Gregorio Olmos: "Outros ao campo saíam,/ $E$ a fazenda percorriam,/ $E$ as manadas ajuntavam;/ E tão rápido passavam/ As horas, que nem sentiam." (Hernández, José (1991). Martin Fierro, Rio de Janeiro: Ediouro, p. 15).

${ }^{24}$ Velázquez, Luis Horacio (1949). Los Años Conmovidos, Buenos Aires: Guillermo Kraft, p. 20, p. 176. "Que brisa tão agradável. Na Capital respiramos gases, não ar." [Tradução do autor].

${ }_{25}$ Para o peronismo, as mulheres deveriam priorizar o papel de esposas e mães. No entanto, Evita 
Em El Juramento, também notamos o interior como uma espécie de "reserva moral". Alcides, contrariado com o novo casamento da mãe, que era viúva, seguiu para o interior, ocasião na qual conheceu Pardo Bayoco. Apesar de ser um homem muito simples, Bayoco seria detentor de um "verdadeiro" saber, pautado em sua experiência de vida.

Em meados do século XX, o Estado argentino está consolidado, mas as passagens anteriores indicam como a oposição entre interior e capital permanece fortemente relacionada com práticas culturais - casamento, relação com o tempo e o espaço, vestimenta, etc. -, centrais na caracterização dos personagens. Apesar da valorização distinta quanto ao interior e aos setores populares, o peronismo defendia a mudança de práticas atribuídas à sua base social, tendo em vista a sua integração/normatização, como se vê na própria obra de Luis Horacio Velázquez.

Apesar da influência de outras tradições literárias como o naturalismo e o realismo, consideramos que a obra do escritor seja marcada essencialmente pelo melodrama. O melodrama marcou a literatura argentina no "boom" de seu mercado editorial, ocorrido nas primeiras décadas do século XX. No melodrama, o amor - pela esposa, pela prole, pelos humildes, pela pátria, etc. - supera as diferenças culturais, sociais e políticas, as quais são encaminhadas para um confronto entre bons e maus e não entre classes. Isabella Cosse, citando Pablo Pérez Rubio, especialista em cinema melodramático, destaca que, no melodrama, não há espaço para rebelião, mas apenas para a reparação. ${ }^{26} \mathrm{E}$, como se observa em Luis Horacio Velázquez, para o peronismo, a mudança de práticas tendo em vista a integração/normatização dos setores populares passava necessariamente pela conciliação nacional e de classes.

Em Pobres Habrá Siempre, apesar do enfrentamento dos trabalhadores com as forças policiais, os líderes operários se esforçam para controlar os trabalhadores: "Morir es desertar de la pelea..."27, alerta um deles. As greves também deveriam ser precedidas

lamentava que muitas mulheres "Trabajan casi como ellos [os homens]. Prefieren, como ellos, la calle a la casa. No se resignan a ser madres, ni esposas." (Perón, Eva (1996a). Por que soy Peronista y las Fuerzas Espirituales del Peronismo, Buenos Aires: C. S. Ediciones, p. XL). "Trabalham quase como eles [os homens]. Preferem, como eles, mais a rua do que a casa. Não se resignam a ser mães, nem esposas." [Tradução do autor]. Ainda de acordo com Evita, como esposas, as mulheres deveriam evitar o luxo e gastos desnecessários, "[...] para consolidar y sostener el salario real de la economia peronista." (Perón, Eva (1996b). Yo Evita: habla a las mujeres, patria - pueblo - recuperación, Buenos Aires: C. S. Ediciones, p. 95). "[...] para consolidar e manter o salário real da economia peronista." [Tradução do autor].

${ }^{26}$ Cosse, Isabella (2006). Estigmas de Nacimiento: peronismo y orden familiar (1946-1955), Buenos Aires: Fondo de Cultura Económica; Universidad de San Andrés, p. 70.

${ }^{27}$ Velázquez, L. H. (1944). Op. Cit., p. 178. "Morrer é fugir da luta..." [Tradução do autor]. 
por negociações: antes da greve que vitima Rafael, uma comissão de trabalhadores expôs as reivindicações aos dirigentes da fábrica. A greve, assim, deveria ser o último recurso. Ainda no início do texto, o narrador destaca a "obediência forçada" e a "resistência passiva" como características positivas dos trabalhadores, especialmente dos argentinos. Mesmo tendo sido necessário recorrer à greve, a defesa da conciliação persiste em Pobres Habrá Siempre. Rafael, o jovem rico que ensinava os trabalhadores a ler e escrever, morre durante a greve, acreditando, porém, no advento de uma Argentina "fraterna e tutelar".

Em Los Años Conmovidos, Roberto e os seus companheiros preparam um jornal para anunciar uma revolta, mas com as seguintes orientações aos trabalhadores: "[...] no paralicen producción ni trabajo - [...] - Respetar vidas, evitar represalias, asegurar orden..."28 Em outra passagem, Roberto é tomado pelo desejo de matar os inimigos políticos da causa que defendia. Entretanto, o desejo, "legítimo", não deveria se tornar uma prática: "[...] esto se pensaba, solamente." 29

Em El Juramento, Alcides faz uma ponderação depois de recordar a visão da avó sobre os estrangeiros, aos quais via como ladrões: "Yo creo que heredé largo tiempo esa condición, como un prejuicio. Mucho me costó cambiarla. Claro, después lo supe, había dos clases de extranjeros..." ${ }^{30}$ Uma vez no poder, o peronismo se vê diante da necessidade de controlar o que outrora tinha alimentado a militância, tendo em vista a conciliação nacional e de classes.

Em El Juramento, a necessidade de controlar a atuação dos trabalhadores aparece, sobretudo, na representação do 17 de outubro de 1945. O dia é citado indiretamente como "a jornada de esperança do décimo mês", liderada por um "povo valente". ${ }^{31}$ Durante essa "jornada", quando Alcides e os seus companheiros passam diante da sede de um jornal da oposição, um dos manifestantes sugere que o prédio fosse incendiado. O narrador se refere ao jornal como um representante do imperialismo. O prédio no qual funcionava o jornal até que "[...] merecería la purificación de las

\footnotetext{
${ }^{28}$ Velázquez, L. H. (1949). Op. Cit., p. 15. "[...] não paralisem a produção nem o trabalho - [...] - Respeitar vidas, evitar represálias, assegurar a ordem..." [Tradução do autor].

${ }^{29}$ Ibidem, p. 280. "[...] isto apenas se pensava." [Tradução do autor].

${ }^{30}$ Velázquez, L. H. (1954a). El Juramento, Buenos Aires: Emecé, p. 24. "Eu acredito que herdei por muito tempo essa visão, como um preconceito. Eu demorei para mudá-la. Claro, depois soube, havia dois tipos de estrangeiros..." [Tradução do autor].

${ }^{31}$ Ibidem, p. 146.
} 
llamas"32, mas nada acontece. O peronismo se preocupou em construir uma memória da data desprovida de atos considerados violentos. ${ }^{33}$ Essa preocupação aparece em outras passagens de El Juramento:

En el trayecto, cercano el mediodía, conseguimos provisiones de algún vecino, nos atacaba el hambre. Golpeábamos en los negocios, tomábamos de los puestos lo más necesario para el hambre. No hubo saqueos ni pillajes [grifo meu]. Galletas, pan, algún fiambre, frutas. Y cigarrillos. Los camiones y carritos de los quinteros se ponían a nuestro servicio. ${ }^{34}$

Ainda sobre o 17 de outubro de 1945, a necessidade de normatizar os trabalhadores aparece no trecho no qual comemoram a libertação do "nosso amigo", entenda-se Perón. “Se levantó [...] un rumor multitudinario: ‘¿Dónde estuvo?’ Hubo una pausa de angustia. La respuesta fué el perdón [grifo meu]." ${ }^{35}$ Nesse ponto notamos a defesa da (re)conciliação de classes.

Marcela Gené destaca que a normatização dos trabalhadores a partir da memória do 17 de outubro também pode ser notada em imagens divulgadas pela propaganda peronista: as imagens de um grande número de trabalhadores de perfil, as quais dariam aos observadores a sensação de terem participado da mobilização naquele dia, perdem gradualmente espaço para imagens nas quais os trabalhadores são representados isoladamente, observando Perón em postura de submissão e passividade. ${ }^{36}$

$\mathrm{Na}$ obra de Luis Horacio Velázquez chama a atenção o lugar ocupado pelos intelectuais e pela cultura letrada nesse processo de normatização dos setores populares.

\footnotetext{
32 Ibidem, p. 148. "[...] merecia a purificação das chamas" [Tradução do autor].

${ }^{33}$ Em A Razão de Minha Vida, Evita destaca que Perón estava sereno quando foi preso e que teria the pedido calma. Ao ressaltar isso, Evita nos apresenta, através de Perón, o trabalhador peronista ideal. Também transcreve o que teria sido uma carta de Perón para ela enquanto esteve preso. "Toma [sic] conta dos meus trabalhadores; tranquiliza-os; que não se preocupem por mim; exorta-os a fugir de tôda violência...[grifos meus]" (Perón, Eva. (1950). A Razão de Minha Vida, Rio de Janeiro: Freitas Bastos, p. 41).

34 Velázquez, L. H. (1954a). Op. Cit., p. 150. "No caminho, perto do meio-dia, conseguimos alimentos de algum vizinho, nos atacava a fome. Batíamos nas lojas, pegávamos apenas o necessário para comer. Não houve saques nem pilhagens. Bolachas, pão, algum embutido, frutas. E cigarros. Os caminhões e carrinhos dos chacareiros se colocavam a nosso serviço." [Tradução do autor]. Nota-se um claro contraponto ao denunciado pela imprensa antiperonista logo após o 17 de outubro de 1945. "Otro grupo asaltó (...) la Cervecería Argentina Quilmes [...], consiguiendo muchos de los manifestantes penetrar en su interior y apoderarse de barriles y cajones con botellas de cerveza [...]." (La Prensa, 19 out. 1945, p. 6 apud Rossi, Luis Alejandro (1998). "Borges, Bioy Casares y el Peronismo". In Estudios Sociales, n. 14, p. 82. Disponível em: <http://www.academia.edu/1950183/Borges_Bioy_Casares_y_el_Peronismo>. Acesso em: 17 jan. 2013). "Outro grupo atacou [...] a Cervejaria Argentina Quilmes [...], conseguindo muitos manifestantes penetrar em seu interior e se apoderar de barris e caixas com garrafas de cerveja [...]." [Tradução do autor].

${ }^{35}$ Velázquez, L. H. (1954a). Op. Cit., p. 154. "Se levantou [...] um rumor multitudinário: 'Onde esteve?' Houve uma pausa angustiante. A resposta foi o perdão." [Tradução do autor].

${ }^{36}$ Gené, Marcela (2005). Un Mundo Feliz: imágenes de los trabajadores en el primer peronismo (19461955), Buenos Aires: Fondo de Cultura Económica; Universidad de San Andrés.
} 
A universidade, os intelectuais, os estudantes e a cultura letrada não são em si criticados. A crítica, quando aparece, não costuma ser generalizada e reside, principalmente, na necessidade de usar as instituições educacionais e a cultura letrada na "defesa" dos interesses populares. ${ }^{37}$

Em Pobres Habrá Siempre, os artistas e estudantes são apresentados como sinceros, qualidade independente da condição econômica: Héctor ensina os trabalhadores a ler e escrever com o auxílio de Rafael, o jovem rico que morreria na greve. Professores, estudantes e jornalistas são, inclusive, colocados ao lado dos operários como vítimas da violência policial. A cultura letrada aparece como um instrumento capaz de orientar os trabalhadores para libertá-los dos "doutores" e "caudilhos de comitê". 38

Em El Juramento, Alcides, outros estudantes e seu amigo Alberto, operário, fundam a Escola de Oradores e Cronistas do Povo com o objetivo de formar líderes e ampliar o espaço que os trabalhadores possuíam na imprensa. Em Los Años Conmovidos, Roberto, preso, foge e se refugia em uma universidade, onde é ajudado pelos alunos, professores e, inclusive, pelo reitor. Aos companheiros de militância, defende a necessidade de educar os setores populares: "[...] no miremos para atrás. El pueblo no tiene la culpa. Es necesario orientarlo para que resurja de esta época vergonzosa de decadencia y de inmoralidad." 39

Desse modo, nas obras de Luis Horacio Velázquez não se questiona o papel tradicionalmente exercido pelos intelectuais. Em El Juramento, os estudantes são representados como a "consciência nacional", já que os trabalhadores teriam que "garantir o sustento dos familiares". Ainda em El Juramento, apesar de Nemesio ter ajudado a fundar uma biblioteca na pequena vila onde morava, defendia que o governo deveria priorizar a construção de escolas técnicas, onde se ensinaria "menos música e gramática" para que os jovens aprendessem a "arar bem a terra". 40

\footnotetext{
${ }^{37}$ Perón se dirigiu aos intelectuais em mais de uma ocasião. Por exemplo, em 13 de novembro de 1947, perante uma comissão de intelectuais, Perón declarou que estes deveriam "[...] agruparse en una sola organización para luchar por la obtención del objetivo común a todos: el objetivo de la Nación." (Perón, Juan Domingo (1947). El Presidente de la Nación Argentina, Gral. Juan Perón, se dirige a los intelectuales, escritores, artistas pintores y maestros, p. 19). "[...] se agrupar em uma única organização para lutar pela obtenção do objetivo comum a todos: o objetivo da Nação." [Tradução do autor].

${ }^{38}$ Velázquez, L. H. (1944). Op. Cit., p. 100.

39 Velázquez, L. H. (1949). Op. Cit., p. 276. "[...] não olhemos para trás. O povo não tem a culpa. É necessário orientá-lo para que ressurja desta época vergonhosa de decadência e de imoralidade." [Tradução do autor].

${ }^{40}$ Velázquez, L. H. (1954a). Op. Cit., p. 137.
} 
O discurso normativo presente na obra de Luis Horácio Velázquez abrange outras dimensões da vida pública e, também, da privada. Eva Perón defendia que o peronista deveria ser movido por "forças espirituais": em Por qué soy Peronista y las Fuerzas Espirituales del Peronismo, Evita destaca quase duzentas "forças" que deveriam caracterizar os peronistas. O adjetivo espirituais indica a tentativa de sacralização da política estudada por Alcir Lenharo. Para citar outro exemplo, Perón tem um livro chamado Doutrina Peronista. Perón e Evita ainda costumavam se referir ao peronismo como uma mística. Segundo Lenharo, a sacralização da política, baseada no apelo a imagens, mensagens e valores religiosos, visava a "[...] dotar o Estado de uma legitimidade escorada em pressupostos mais nobres do que os tirados da ordem política, funcionando como escudo religioso contra as oposições não debeladas." ${ }^{11}$

Retornando à obra de Luis Horacio Velázquez, a lealdade aparece como outro elemento normativo. Em Pobres Habrá Siempre, os líderes operários não aceitam o suborno oferecido pelos patrões, que queriam o término da greve. Em Los Años Conmovidos, Roberto, embora preso e torturado, não entrega os companheiros de militância. Essas passagens não são casuais. Segundo Evita, a lealdade era uma das "forças espirituais" do peronismo. "[...] [A lealdade] guarda una estrecha analogía con el desinterés; impone la completa eliminación de nuestros propios gustos, esperanzas, deseos e intereses, a fin de que triunfe la causa peronista." ${ }^{22}$ Essa defesa da lealdade é uma crítica às cisões internas que obstaculizavam a unidade peronista:

La prueba de lealtad de un peronista es su acatamiento a las directivas del Jefe [...]. [...]. EL GENERAL PERÓN HA DICHO: El que dentro de nuestro movimiento luche contra otro grupo peronista, para defender intereses personales, es un traidor a nuestra causa. ${ }^{43}$

O trabalho também é exaltado na obra de Luis Horacio Velázquez. Contudo, há uma tensão com uma imagem negativa do trabalho, tensão esta também presente no discurso peronista. Em Por qué soy Peronista y las Fuerzas Espirituales del Peronismo, Evita destaca que "[...] pedir mayor producción a los trabajadores era pedirles que contribuyeran con más sudor, con más sacrificios, con mayores esfuerzos a la riqueza de

\footnotetext{
${ }^{41}$ Lenharo, Alcir (1986). Sacralização da Política, Campinas: Ed. UNICAMP/Papirus, p. 18.

42 Perón, E. (1996a). Op. Cit., p. LI. "[...] [A lealdade] guarda uma estreita analogia com o desinteresse; impõe a completa eliminação de nossas próprias preferências, esperanças, desejos e interesses, a fim de que triunfe a causa peronista." [Tradução do autor].

${ }^{43}$ Ibidem, p. LII. "A prova de lealdade de um peronista é seu acatamento às orientações do Chefe [...]. [...]. O GENERAL PERÓN DISSE: Aquele que dentro de nosso movimento lute contra outro grupo peronista, para defender interesses pessoais, é um traidor de nossa causa." [Tradução do autor].
} 
pocos y a la miseria de muchos [grifos meus]."44 Em Doutrina Peronista, Perón clama (em 23 de agosto de 1947) por "disciplina", "responsabilidade", "vontade" e "empenho" no trabalho e qualifica de "ação criminosa" a diminuição intencional da produtividade. ${ }^{45} \mathrm{O}$ adjetivo criminosa indica a preocupação do governo em normatizar o trabalho de acordo com seus pressupostos. A propósito, para Evita, a produtividade era uma das "forças espirituais" do peronismo. ${ }^{46}$ É apresentada como imprescindível para a prosperidade familiar e do país.

Em Los Años Conmovidos, Roberto não aceita um emprego na prefeitura, pois teria que militar para um caudilho local, o Doutor Miranda. É representado, assim, como um trabalho honesto, desinteressado. Prefere trabalhar como ajudante de pedreiro, o que lhe dá a experiência necessária para, depois, cuidar de uma quinta e ser vendedor. "Los músculos domesticados y obedientes en [...] los andamios lo habían transformado en un hombre dinámico y seguro de sí mismo." ${ }^{77}$ Porém, chama a atenção o desânimo dos ajudantes que Roberto contrata enquanto estava na quinta, os quais desistem rapidamente do emprego. Um dos ajudantes é descrito como um rapaz "[...] receloso, de mirada huidiza, callado." ${ }^{48}$ Ou seja, Roberto prospera porque trabalha. É interessante como existe uma convergência com o princípio liberal segundo o qual as diferenças sociais seriam explicadas pelos méritos pessoais.

Em El Juramento, a mãe de Alcides fica envergonhada por ele ter sido visto trabalhando em uma feira quando era criança. Já sua avó Encarnación defende a importância do trabalho para a formação de um homem, mas é interessante que a sua fala seja iniciada pelo comparativo irregular de mau: "jPeor es que robe!" [grifo meu]. ${ }^{49}$

Outro elemento do discurso peronista é o papel esperado das mulheres. Em Pobres Habrá Siempre, as mulheres apresentam uma militância que, não por acaso, é suavizada nas demais narrativas, publicadas depois que Perón se tornou presidente. No livro, as mulheres participam da comissão que apresenta as reivindicações aos patrões e, na greve que vitima Rafael, clamam para que os trabalhadores "covardes" participassem

\footnotetext{
${ }^{44}$ Perón, E. (1996a). Op. Cit., p. 72. "[...] pedir maior produção aos trabalhadores era lhes pedir que contribuíssem com mais suor, com mais sacrifícios, com maiores esforços para a riqueza de poucos e a miséria de muitos." [Tradução do autor].

${ }^{45}$ Perón, J. D. (1996). Doctrina Peronista, Buenos Aires: C. S. Ediciones, p. 252.

${ }^{46}$ Perón, E. (1996a). Op. Cit., p. LXVI.

47 Velázquez, L. H. (1949). Op. Cit., p. 121. "Os músculos domesticados e obedientes [...] nos andaimes tinham Ihe transformado em um homem dinâmico e seguro de si mesmo." [Tradução do autor].

${ }^{48}$ Ibidem, p. 135. "[...] receoso, de olhar esquivo, calado." [Tradução do autor].

${ }^{49}$ Velázquez, L. H. (1954a). Op. Cit., p. 26. "Pior é roubar?" [Tradução do autor].
} 
do movimento. Entretanto, essa militância entraria em contradição com a "natureza feminina", supostamente voltada para o ambiente doméstico. No trabalho, as mulheres vivem pensando nos filhos. Uma das operárias chega a abortar por excesso de trabalho. As solteiras, como precisam colaborar com as despesas familiares, adiam o casamento e a maternidade, apresentados como sonhos femininos. As mulheres enfrentam ainda a ameaça da "desonra", pelo assédio sexual que sofriam dos seus superiores.

Já nas outras narrativas, as mulheres têm a possibilidade de se realizarem de acordo com "sua natureza". Em Los Años Conmovidos, Beatriz, após se casar com Roberto, apenas dá aulas de reforço para auxiliar nas despesas domésticas, pois se dedica, sobretudo, a cuidar da casa e das crianças, representando assim o já citado modelo de mulher defendido pelo discurso peronista, uma mulher ligada ao lar e à família, responsável pela prosperidade econômica familiar ${ }^{50}$ e submissa ao marido. ${ }^{51}$ Submissa a ponto de perdoar a traição amorosa de Roberto com Emilce. Em Los Años Conmovidos são destacadas a limpeza da quinta e das crianças de Roberto e Beatriz:

Después de partir Roberto, Beatriz limpió la casa [...]. De lejos, parecía una simple casilla de madera y cinc [...]; daba espaldas al camino y los visitantes al llegar, recibían una impresión muy pobre de ella. Mas era el ámbito inexpresable de su felicidad. Su gracia era íntima: los pisos eran de mosaicos lustrados [...].

Los niños se despertaron rezongando por la merienda [...]. Beatriz les dió el desayuno, los vistió, los lavó y los compuso amorosamente. ${ }^{52}$

Em El Juramento encontramos representações parecidas. Ao lembrar a sua infância, Alcides menciona as mulheres da vizinhança que "penteavam as suas crianças", "faziam a comida”, "arrumavam a casa" e "esperavam papai chegar”: "iQué encantador es el juego de los oficios!" 53

Os homens, por sua vez, colaboram com a harmonia e a prosperidade econômica do lar evitando os vícios e os relacionamentos extraconjugais. Em Los Años Conmovidos,

\footnotetext{
50 "[...] como la mayoría de los hombres, [Roberto] era manirroto y descuidado para gastar, pues no tenía noción del valor del dinero." (Velázquez, L. H. (1949). Op. Cit., p. 126). "[...] como a maioria dos homens, [Roberto] era mão-aberta e descuidado para gastar, pois não tinha noção do valor do dinheiro." [Tradução do autor].

51 "[...] sufre por su dolor, porque lo ve extenuado [...], pero sabe bien que sufriría más si le reprochara." (Ibidem, p. 111). "[...] sofre por ele, porque the vê extenuado [...], mas sabe que ele sofreria mais se lhe criticasse." [Tradução do autor].

52 Ibidem, p. 206. "Após Roberto sair, Beatriz limpou a casa [...]. De longe, parecia uma simples casinha de madeira e zinco [...] davam os fundos para a rua e os visitantes ao chegar, tinham uma impressão muito pobre dela. Mas era o espaço inexpressável de sua felicidade. Sua graça era íntima: os pisos eram de mosaicos lustrados [...]. As crianças acordaram resmungando pedindo a merenda [...]. Beatriz Ihes deu 0 café, Ihes vestiu, Ihes lavou e Ihes arrumou amorosamente." [Tradução do autor].

${ }^{53}$ Velázquez, L. H. (1954a). Op. Cit., p. 33. "Que encantadora é a divisão das tarefas!" [Tradução do autor].
} 
Don Luigi, ajudante de Roberto e Beatriz na quinta, morre atropelado por um trem após se embebedar. Roberto é um homem "sério", que não aceita convites para jogar, mas quando se envolve com Emilce, sua amante, passa a vender bem menos no trabalho. Essa relação entre relacionamentos extraconjugais e problemas econômicos aparece novamente na passagem em que Roberto, após terminar seu caso com Emilce, se reconcilia com sua esposa Beatriz. A reconciliação é marcada pela compra de um automóvel:

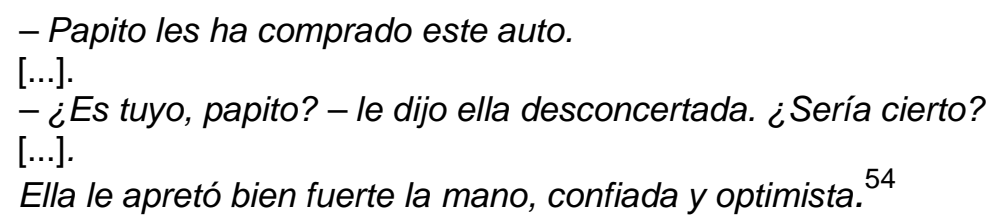

Além do relacionamento extraconjugal de Roberto, na obra de Luis Horacio Velázquez existem inúmeras outras passagens que indicam empecilhos para se concretizar o que Isabela Cosse chama de "ideal de domesticidade". De acordo com a autora, esse ideal "[...] demarcaba el "deber ser" para varones y mujeres, pautaba la vida cotidiana, dibujaba [...] las conductas apropiadas para las relaciones de pareja y entre padres e hijos, conectando el orden familiar con el social." ${ }^{55} \mathrm{Em}$ El Juramento, apesar das lembranças de infância, nas quais as mulheres e crianças "esperavam papai chegar", Alcides, ao recordar da adolescência, diz que todos os meninos que tinham irmãs falavam delas com um "pudor temeroso"56:

El Cacho se puso colorado de vergüenza. No, ciertamente, él no podía jurar que su hermana se casaría con su novio. Le parecía que todos veíamos a la linda Diana deshonrada y sin casarse. Sentía súbitamente un tremendo rencor contra ella, ganas de ir a pelearlo al novio. ${ }^{57}$

Desse modo, à imagem idealizada da infância é contraposta outra, marcada por medo e confronto, resultantes da descoberta da sexualidade na adolescência. Entretanto, a narrativa aponta para a possibilidade de se concretizar a imagem idealizada. Alcides, o

\footnotetext{
${ }^{54}$ Velázquez, L. H. (1949). Op. Cit., p. 309. "- Papai comprou este carro para vocês. [...]. - É seu, papai? ela Ihe disse desconcertada. Seria prudente? [...]. Ela lhe apertou bem forte a mão, confiante e otimista." [Tradução do autor].

${ }^{55}$ Cosse, I. (2006). Op. Cit., p. 31. "[...] demarcava o "dever ser" para homens e mulheres, pautava a vida cotidiana, desenhava (...) as condutas apropriadas para as relações dos casais e entre pais e filhos, conectando a ordem familiar com a social." [Tradução do autor].

${ }^{56}$ Velázquez, L. H. (1954a). Op. Cit., p. 65.

${ }^{57}$ Ibidem, p. 65. "O Cacho ficou vermelho de vergonha. Não, certamente, ele não podia jurar que sua irmã se casaria com o namorado. Pensava que todos víamos a linda Diana desonrada e sem se casar. Sentia subitamente um tremendo rancor contra ela, vontade de ir brigar com o namorado." [Tradução do autor].
} 
protagonista, não se "corrompe": quando vai com amigos a um prostíbulo de Ensenada, não consegue entrar e se surpreende com os frequentadores do local. “¿A qué irían allá, si parecían todos casados y tenían mujer? Muchos eran señores respetables, hasta con barba." ${ }^{58}$ Logo depois desse episódio, Alcides se encontra com Blanquita, a sua "prometida" e ambos interpretam um trecho de um livro no qual um casal declara seu amor um pelo outro. Trata-se de uma passagem de clara função metalinguística, em que se evidencia a crença de Luis Horacio Velázquez - e do peronismo - no papel moralizante/normativo da literatura.

\section{Conclusão}

Enfim, existe na obra de Luis Horacio Velázquez uma clara transposição do discurso peronista para a literatura, o que demonstra uma ação coordenada do governo de Perón na esfera cultural. O escritor não ocupou por acaso o cargo de presidente da Comissão Protetora de Bibliotecas Populares. A Comissão, ainda existente, é o órgão estatal que regula a fundação e manutenção das bibliotecas populares, o que, vale lembrar, são essencialmente iniciativas da sociedade civil. Consideramos, assim, que a trajetória de Luis Horacio Velázquez é representativa da relação do governo de Perón com os escritores e intelectuais: mais do que meramente apoiá-lo, estes deveriam colocar sua obra a serviço do peronismo para conscientizar os setores populares quanto aos pilares da "nova" Argentina.

As tensões que marcam os discursos de Perón e Evita são os motores de suas narrativas, de modo a exaltar a redenção dos personagens que seguem os pressupostos defendidos, o que dá aos textos um forte cunho pedagógico. Porém, em sua obra predominam redenções individuais ou de grupos restritos como a família de Roberto e Beatriz em Los Años Conmovidos. Ainda que possamos ler a família de Roberto e de Beatriz como uma metáfora da sociedade argentina, nos outros dois livros a redenção coletiva existe apenas em um plano ideal, o que, acreditamos, indica a existência de entraves para a construção da sociedade defendida pelo peronismo. Já mencionamos a morte de Rafael em Pobres Habrá Siempre, projetando apenas para o futuro uma Argentina "fraterna e tutelar". Em El Juramento, Cristina, a esposa de Alberto, a qual tinha

\footnotetext{
${ }^{58}$ Ibidem, p. 65. "Por que iriam lá, se pareciam todos casados e tinham mulher? Muitos eram senhores respeitáveis, tinham até barba." [Tradução do autor].
} 
origem francesa, se refere à Argentina como uma espécie de terra prometida: “- [...] la tierra de ustedes es tan generosa y buena, Alcides...;Qué felices y seguros deben sentirse los argentinos en su tierra! ${ }^{59}$. Entretanto, no mesmo livro, essa percepção destoa dos vilarejos encontrados por Alcides em uma viagem pelo interior: "Claro, existen ranchos sucios y gente miserable, enferma todavía de hambre y de tristeza. No todo en un momento se puede concluir. Ni Dios pudo, con toda su buena voluntad, hacer el mundo en un solo dia". 60

Não podemos concluir que os setores populares não adotaram princípios peronistas em suas práticas cotidianas, ou que não adotaram como o governo gostaria. De qualquer modo, a obra de Luis Horacio Velázquez sugere que esta parecia ser a percepção do peronismo ou de setores dele, pelo menos em questões como a autonomia e/ou "violência" dos trabalhadores, a valorização do trabalho, a defesa dos papéis tradicionalmente atribuídos às mulheres e a crítica aos vícios e aos relacionamentos extraconjugais. A obra do escritor demonstra, juntamente com os discursos de Perón e Evita, como o peronismo possuía um projeto de sociedade que ia muito além dos âmbitos político-partidário e sindical. E as tensões que marcam as narrativas de Luis Horacio Velázquez indicam a distância entre esse projeto e sua concretização. O próprio Perón reconheceu que o discurso e a propaganda política representam, justamente, a ausência da mensagem que veiculam na sociedade para a qual se destinam:

No hay que poner tanto peronismo en las paredes como persuadir a la población de que el peronismo es la verdadera causa.

[...].

El día que lo logremos, quizá no será necesario poner un cartel más en la calle. ${ }^{61}$

A obra de Luis Horacio Velázquez é apenas uma das ações do peronismo na esfera cultural. Assim como a sua obra nos indica tensões do peronismo com a sua própria base social, existiam divergências entre os próprios peronistas sobre como conceber e conduzir os setores populares. ${ }^{62}$ Cabe à historiografia aprofundar a visão

\footnotetext{
${ }^{59}$ Ibidem, p. 181. "- [...] a terra de vocês é tão generosa e boa, Alcides...Que felizes e seguros devem se sentir os argentinos em sua terra!" [Tradução do autor].

${ }^{60}$ Ibidem, p. 120. "Claro, existem ranchos sujos e gente miserável, ainda doente de fome e de tristeza. Não é possível fazer tudo de uma hora para outra. Nem Deus pode, com toda a sua boa vontade, fazer o mundo em um único dia." [Tradução do autor].

${ }^{61}$ Perón, Juan Domingo (1973). Conducción Política, Buenos Aires: Freeland, p. 308. "Não temos que pregar tanto o peronismo nas paredes mas convencer a população de que o peronismo é a verdadeira causa. [...]. O dia em que conseguirmos isso, talvez não seja mais necessário colocar nenhum cartaz na rua." [Tradução do autor].

${ }^{62}$ Ver: Silva, Paulo Renato da (2010). "Peronismo e Cultura: o Primeiro Congresso de Bibliotecas Populares
} 
sobre o período para além da bipolarização peronismo versus antiperonismo e levantar as divergências internas que existiam em ambos os grupos.

\section{Referências}

Campodónico, H. (1998). "Pobres Habrá Siempre (Luis Horacio Velázquez/Carlos Borcosque)". In Segundas Jornadas Internacionales de Literatura Argentina/Comparatística: actas, Buenos Aires: Instituto de Literatura Argentina "Ricardo Rojas", p. 81-101.

Capelato, Maria Helena Rolim (2009). Multidões em Cena: propaganda política no varguismo e no peronismo. 2. ed, São Paulo: Ed. UNESP.

Certeau, Michel de (1995). A Cultura no Plural, Campinas: Papirus.

Chávez, Fermín (2004). Alpargatas y Libros: diccionario de peronistas de la cultura II, Buenos Aires: Theoría.

Cosse, Isabella (2006). Estigmas de Nacimiento: peronismo y orden familiar (1946-1955), Buenos Aires: Fondo de Cultura Económica; Universidad de San Andrés.

Fiorucci, Flavia (2004). “¿Aliados o Enemigos? Los Intelectuales en los Gobiernos de Vargas e Perón." In Estudios Interdisciplinarios de America Latina y el Caribe, v. 15, n. 2. Disponível em: <www.tau.ac.il/eial/XV_2/fiorucci.html>. Acesso em: 2 maio 2005.

Gené, Marcela (2005). Un Mundo Feliz: imágenes de los trabajadores en el primer peronismo (1946-1955), Buenos Aires: Fondo de Cultura Económica; Universidad de San Andrés.

Germani, Gino (1968). Politica y Sociedad en una Epoca de Transicion: de la sociedad tradicional a la sociedad de masas, Buenos Aires: Paidos.

Gutiérrez, Leandro; Romero, Luis Alberto (2007). Sectores Populares, Cultura y Política: Buenos Aires en la entreguerra, Buenos Aires: Siglo XXI.

Hernández, José (1991). Martin Fierro, Rio de Janeiro: Ediouro.

James, Daniel (2004). "Contos narrados nas fronteiras: a história de doña María, história oral e questões de gênero". In Batalha, Claudio H. M; Silva, Fernando Teixeira; Fortes, Alexandre (Org.) (2004). Culturas de Classe: identidade e diversidade na formação do operariado, Campinas, SP: Ed. UNICAMP, p. 287-314. 
King, John (1989). Sur: estudio de la revista argentina y de su papel en el desarrollo de una cultura (1931-1970), Cidade do México: Fondo de Cultura Económica.

Lenharo, Alcir (1986). Sacralização da Política, Campinas: Ed. UNICAMP/Papirus.

Luna, Félix (1986). Perón y su Tiempo, Buenos Aires: Sudamericana, v. 1.

Perón, Eva (1950). A Razão de Minha Vida, Rio de Janeiro: Freitas Bastos.

(1996a). Por que soy Peronista y las Fuerzas Espirituales del Peronismo, Buenos Aires: C. S. Ediciones.

(1996b). Yo Evita: habla a las mujeres, patria - pueblo - recuperación, Buenos Aires: C. S. Ediciones.

Perón, Juan Domingo (1947). El Presidente de la Nación Argentina, Gral. Juan Perón, se dirige a los intelectuales, escritores, artistas pintores y maestros: filosófica, política, social, Buenos Aires.

(1973). Conducción Política, Buenos Aires: Freeland.

(1996). Doctrina Peronista, Buenos Aires: C. S. Ediciones.

Plotkin, Mariano Ben (2007). Mañana es San Perón: propaganda, rituales políticos y educación en el régimen peronista (1946-1955), Caseros: Editorial de la Universidad Nacional de Tres de Febrero.

La Prensa (1954), Buenos Aires, 6 de outubro.

Rossi, Luis Alejandro (1998). "Borges, Bioy Casares y el Peronismo". In Estudios Sociales, $\quad$ n. 14.10 Disponível <http://www.academia.edu/1950183/Borges_Bioy_Casares_y_el_Peronismo>. Acesso em: 17 jan. 2013.

Sarlo, Beatriz (1997). "Buenos Aires, Cidade Moderna". In Paisagens Imaginárias: intelectuais, arte e meios de comunicação. São Paulo: EDUSP, p. 199-217.

(2004). El Imperio de los Sentimientos: narraciones de circulación periódica en la Argentina (1917-1927), Buenos Aires: Norma.

Sarmiento, Domingo Faustino (1996). Facundo: civilização e barbárie, Petrópolis: Vozes.

Silva, Paulo Renato da (2010). "Peronismo e cultura: o Primeiro Congresso de Bibliotecas Populares da Província de Buenos Aires (1949)". In Topoi, Rio de Janeiro, v. 21, p. 222234.

Swiderski, Graciela (Org.) (1997). Biblioteca Juan Domingo Perón: bibliografía sobre el peronismo, Buenos Aires: Archivo General de la Nación. 
Velázquez, Luis Horacio (1954a). El Juramento, Buenos Aires: Emecé.

(1954b). Guia de Bibliotecas Argentinas, Buenos Aires: Ministerio de Educación de la Nación; Dirección General de Cultura; Comisión Protectora de Bibliotecas Populares, t. 1.

Velázquez, Luis Horacio (1949). Los Años Conmovidos, Buenos Aires: Guillermo Kraft. (1944). Pobres Habrá Siempre, Buenos Aires: Claridad.

Recebido para publicação em janeiro de 2013.

Aprovado para publicação em março de 2013. 